\title{
Legislative activity related to the human papillomavirus (HPV) vaccine in the United States (2006-2015): a need for evidence-based policy
}

This article was published in the following Dove Press journal:

Risk Management and Healthcare Policy

13 March 2017

Number of times this article has been viewed

\section{Jessica Keim-Malpass ${ }^{1,2}$ \\ Emma M Mitchell' \\ Pamela B DeGuzman' \\ Mark H Stoler ${ }^{3}$ \\ Christine Kennedy ${ }^{1,2}$}

'School of Nursing, ${ }^{2}$ Department of Pediatrics, ${ }^{3}$ Department of Pathology, School of Medicine, University of Virginia, Charlottesville, VA, USA
Correspondence: Jessica Keim-Malpass School of Nursing, University of Virginia, PO Box 800782, Charlottesville, VA 22908, USA

$\mathrm{Tel}+\mathrm{I} 6363466855$

Fax +I 4349242787

Email jlk2t@virginia.edu

\begin{abstract}
State-based policies to mandate HPV vaccination are politically challenging and have received broad criticisms. There is a critical need to understand the legislative activities that underpin subsequent policy implementation. The objective of this policy analysis was to analyze state legislation that focused on HPV vaccination from 2006-2015. A content analysis was conducted among primary sources of legislative data from HPV vaccine-related bills, including using the National Conference of State Legislatures as a search-source. Findings reveal that much of the legislative activity occurred early after the HPV vaccination was introduced, and focused on increased information for parents, public financing, awareness campaigns, etc. Far fewer states focused on voluntary or mandatory vaccination. Understanding the barriers to achieving mandatory vaccination policy and implementation of such policies for HPV vaccines remains a public health priority.
\end{abstract}

Keywords: HPV vaccine, adolescent, policy, legislation

\section{Introduction}

The development of human papillomavirus (HPV) vaccines has been touted as a tremendous public health achievement for the potential prevention of cervical, vulvar, vaginal, anal, penile, and oropharyngeal cancer. The first HPV vaccine was initially approved by the US Food and Drug Administration (FDA) in 2006, and the newest nonavalent vaccine was approved in 2015. ${ }^{1}$ The Advisory Committee on Immunization Practices (ACIP) added the HPV vaccination to the immunization schedule for adolescent girls aged 11-12 years in 2006, and the recommendation was extended to males in 2010 . $^{2}$ Even so, the uptake and completion of the HPV vaccine's three-vaccination series has dramatically lagged behind anticipated rates, ${ }^{3}$ and increased immunization coverage remains a public health priority and Healthy People 2020 goal. $^{4}$

State-based policies to mandate HPV vaccination are politically challenging, due to the fact that the vaccine protects against a sexually transmitted infection, and parental concerns with the vaccine have been widely documented. ${ }^{1,5}$ Some of the few states who were early adopters of mandatory vaccination for girls have enacted repeals, faced criticism for broad opt-outs, and have not yet passed legislation requiring the HPV vaccine for young males. ${ }^{5}$ Additionally, there is very little evidence of the impact of vaccination policies on uptake and completion of the vaccine. Laugesen $\mathrm{et}^{\mathrm{al}} \mathrm{l}^{5}$ performed an early policy analysis related to the HPV vaccine, focusing on the years immediately following the vaccination release and prior to the FDA approval for young men. There is a critical need to understand the updated legislative landscape for policies related to the HPV vaccine so that research initiatives can study the effect of policy on HPV- 
related outcomes. The objective of this policy analysis was to analyze state legislation that focused on HPV vaccination from 2006 to 2015.

\section{Materials and methods}

This study utilized a descriptive content analysis to examine and code sources of data from HPV vaccine-related bills. The National Conference of State Legislatures (NCSL) ${ }^{6}$ was consulted as a beginning search source, and provided an overview of HPV vaccine-related legislation. The NCSL is a publicly accessible website that organizes all bills that are related to HPV vaccination by year they were introduced and year enacted (if applicable). After consulting the NCSL, individual bills were read and abstracted to determine the type of legislation based on a priori legislative categories: 1) mandated vaccine, females; 2) mandated vaccine, males; 3) public funding offered; 4) mandated private health-insurance coverage of vaccine; 5) provided for vaccine-information delivery; 6) provided HPV-related awareness campaign; 7) bills supporting voluntary vaccination; 8) political backlash and/or mandate-reversal bills; and 9) other HPV vaccine-related legislation.

\section{Results}

Only six states have not set forth HPV-vaccine legislation (Table 1), and the vast majority of states introduced legislation in the year following initial FDA approval of the HPV vaccine (Figure 1). Far fewer states have been successful with passage of the proposed legislation, and most of the bills enacted focus on awareness campaigns, vaccine information, ensuring private coverage, and public funding. By 2007, 24 states and Washington DC had proposed legislation mandating the HPV vaccine for school attendance, with very little

Table I States introducing and enacting human papillomavirus-vaccine legislation (2006-20I5)

\begin{tabular}{|c|c|c|c|c|c|c|c|c|c|c|}
\hline State & $\begin{array}{l}\text { Mandated } \\
\text { vaccine } \\
\text { (females) }\end{array}$ & $\begin{array}{l}\text { Mandated } \\
\text { vaccine } \\
\text { (males) }\end{array}$ & $\begin{array}{l}\text { Public } \\
\text { funding }\end{array}$ & $\begin{array}{l}\text { Private } \\
\text { coverage }\end{array}$ & $\begin{array}{l}\text { Vaccine } \\
\text { information }\end{array}$ & $\begin{array}{l}\text { Awareness } \\
\text { campaigns }\end{array}$ & $\begin{array}{l}\text { Voluntary } \\
\text { vaccination }\end{array}$ & $\begin{array}{l}\text { Political } \\
\text { backlash }\end{array}$ & Other & None \\
\hline Alabama & & & & & 0 & & 0 & & 0 & \\
\hline Alaska & & & & & & & & & & 斗 \\
\hline Arizona & & & 0 & 0 & & 0 & & & 0 & \\
\hline Arkansas & 0 & & & & & & & & & \\
\hline California & 0 & & & 0 & & & & & & \\
\hline Colorado & 0 & & $\diamond$ & $\diamond$ & $\diamond$ & $\diamond$ & 0 & & $\diamond$ & \\
\hline Connecticut & 0 & & 0 & & & 0 & & & 0 & \\
\hline Delaware & & & & & & & & & & 斗 \\
\hline District of & $\diamond$ & & & & & & & & & \\
\hline Columbia & & & & & & & & & & \\
\hline Florida & 0 & & & 0 & 0 & & & & 0 & \\
\hline Georgia & 0 & & & 0 & 0 & & & & 0 & \\
\hline Hawaii & 0 & 0 & 0 & 0 & 0 & 0 & & & 0 & \\
\hline Illinois & 0 & & $\diamond$ & $\diamond$ & 0 & 0 & & & $\diamond$ & \\
\hline Idaho & & & & & & & & & & 斗 \\
\hline Indiana & & & & & 0 & $\diamond$ & $\diamond$ & & $\diamond$ & \\
\hline lowa & & & 0 & $\diamond$ & 0 & 0 & & & & \\
\hline Kansas & 0 & & & & 0 & & & 0 & & \\
\hline Kentucky & 0 & 0 & 0 & & 0 & 0 & 0 & & & \\
\hline Louisiana & & & & 0 & $\diamond$ & & & & & \\
\hline Maine & & & $\bullet$ & & & $\diamond$ & & & & \\
\hline Maryland & 0 & & & & & & & & $\diamond$ & \\
\hline Massachusetts & 0 & & 0 & & & & & & & \\
\hline Michigan & 0 & & & 0 & $\diamond$ & & & & & \\
\hline Minnesota & 0 & & & & 0 & & & & $\diamond$ & \\
\hline Mississippi & 0 & & & & & & & & & \\
\hline Missouri & 0 & & & 0 & $\diamond$ & & 0 & & 0 & \\
\hline Montana & & & & & & & & & & 果 \\
\hline Nevada & & & & $\diamond$ & & & & & & \\
\hline Nebraska & & & & & & & & & $\diamond$ & \\
\hline New Hampshire & & & & & & & & & & 斗 \\
\hline New Jersey & 0 & 0 & 0 & 0 & $\diamond$ & & & & & \\
\hline New Mexico & 0 & & $\diamond$ & $\bullet$ & 0 & & & & $\diamond$ & \\
\hline
\end{tabular}


Table I (Continued)

\begin{tabular}{|c|c|c|c|c|c|c|c|c|c|c|}
\hline State & $\begin{array}{l}\text { Mandated } \\
\text { vaccine } \\
\text { (females) }\end{array}$ & $\begin{array}{l}\text { Mandated } \\
\text { vaccine } \\
\text { (males) }\end{array}$ & $\begin{array}{l}\text { Public } \\
\text { funding }\end{array}$ & $\begin{array}{l}\text { Private } \\
\text { coverage }\end{array}$ & $\begin{array}{l}\text { Vaccine } \\
\text { information }\end{array}$ & $\begin{array}{l}\text { Awareness } \\
\text { campaigns }\end{array}$ & $\begin{array}{l}\text { Voluntary } \\
\text { vaccination }\end{array}$ & $\begin{array}{l}\text { Political } \\
\text { backlash }\end{array}$ & Other & None \\
\hline New York & 0 & 0 & $\diamond$ & 0 & 0 & & 0 & & 0 & \\
\hline North Dakota & & & & $\diamond$ & & & & & & \\
\hline North Carolina & & & & $\diamond$ & & $\diamond$ & & & & \\
\hline Ohio & 0 & & & 0 & & & & & & \\
\hline Oklahoma & 0 & & & & 0 & & & & & \\
\hline Oregon & & & & $\diamond$ & & & & & $\diamond$ & \\
\hline Pennsylvania & & & & 0 & $\diamond$ & 0 & & & $\diamond$ & \\
\hline Rhode Island & $\diamond \mathscr{H}$ & $\diamond \mathscr{H}$ & & $\diamond$ & & & & & & \\
\hline South Carolina & 0 & & & & & & 0 & & & \\
\hline South Dakota & & & $\diamond$ & & & & & & & \\
\hline Tennessee & & & & & & & & & $\diamond$ & \\
\hline Texas & $\diamond$ & & $\diamond$ & $\diamond$ & $\diamond$ & $\diamond$ & & $\diamond$ & 0 & \\
\hline Utah & & & & & & $\diamond$ & & & & \\
\hline Vermont & 0 & & 0 & & & & & & & \\
\hline Virginia & $\diamond$ & 0 & & 0 & & & & 0 & & \\
\hline Washington & & & & & $\diamond$ & 0 & & & 0 & \\
\hline West Virginia & 0 & & & & & & & & & \\
\hline Wisconsin & & & & & 0 & & & & & \\
\hline Wyoming & & & & & & & & & & 斗 \\
\hline
\end{tabular}

Key: O, Introduced legislation; $\diamond$, enacted legislation; $\mathscr{H}$, enacted through the Rhode Island Department of Health, which has the ability to enact this requirement without legislative action; $*$, legislatures passed HB 1098 to override the previous mandate; $\$$, no legislation introduced.

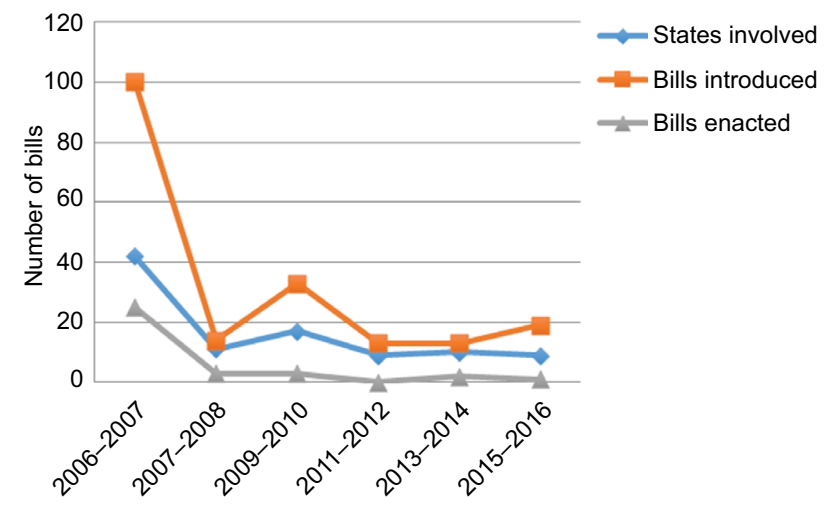

Figure I Human papillomavirus-vaccine legislative activity over time.

success. Currently, only Virginia, Rhode Island, and Washington have successfully enacted legislation requiring mandates for adolescents to begin the vaccine series for school enrollment. Initially, Texas passed a bill requiring the HPV vaccine, but this legislation was later repealed. Currently, Rhode Island is the only state where the mandate covers mandatory vaccination of both young females and males, with both Virginia and Washington only covering females.

Very few states have introduced HPV vaccine-related legislation in recent years (Figure 1). From a federal funding standpoint, two opportunities have been made available - 1) the Vaccine for Children program, which provides the vaccine series at no cost to certain families, and 2) the Affordable Care Act (ACA), which now requires private insurers to provide coverage of ACIP-approved vaccines at no cost to the patient - both of which impact state-policy development for public and private funding.

\section{Discussion}

Understanding barriers to achieving HPV-vaccination policy and implementation of such policies remains a public health priority for those who care for adolescents and young adults. This study provides a critical update to the literature ${ }^{5}$ and examines the existing policy context, while also documenting the need for states to produce and enact evidence-based vaccination policy. Only three jurisdictions have successfully enacted a school mandate for the HPV vaccine, and we have little knowledge to suggest the overall impact of legislation on uptake and completion. From a federal perspective, there is little evidence that evaluates the health-related outcomes of the Vaccine for Children program or ACA provisions. There is a profound gap in understanding the impact of policy on HPVvaccine use and morbidity related to HPV-related diseases.

States play a unique role in the formation and implementation of policies that support public health goals, and will continue to play a central role in vaccination policies and laws. This analysis provides evidence that most HPV-related legislative activities took place in the years immediately following the introduction of the HPV vaccine; this suggests that interest in HPV vaccination has steadily 
declined. A limitation of this current study is that it only assessed legislative language, and not actual state-based appropriation or monetary support for the enacted bills. An additional area of further study involves understanding the political, economic, and legal context that led to various HPV-vaccine legislative 1) bills introduced, 2) bills enacted, and 3) monetary appropriation. Understanding political, economic, and legal antecedents is particularly relevant to legislation involving the HPV vaccine, because of the vaccine's association with sexually transmitted infections and controversial messaging by some stakeholders and media outlets. ${ }^{1}$ Finally, it is necessary to examine communication related to HPV-vaccine legislation in terms of state legislators and the relationship with this discourse and public opinion.

\section{Acknowledgment}

JK-M was financially supported through a grant from NIH/ NCI P30CA044579.

\section{Disclosure}

The authors report no conflicts of interest in this work.

\section{References}

1. Holman DM, Benard V, Roland KB, Watson M, Liddon N, Stokley S. Barriers to human papillomavirus vaccination among US adolescents: a systematic review of the literature. JAMA Pediatr. 2014;168(1):76-82.

2. Markowitz L, Dunne E, Saraiya M, et al. Human papillomavirus vaccination: recommendations of the Advisory Committee on Immunization Practices (ACIP). MMWR Recomm Rep. 2014;63(5):1-30.

3. Reagan-Steiner S, Yankey D, Jeyarajah J, et al. National, regional, state, and selected local area vaccination coverage among adolescents aged 13-17 years: United States, 2014. MMWR Morb Mortal Wkly Rep. 2015; 64(29):784-792.

4. Office of Disease Prevention and Health Promotion. 2020 Topics and objectives: objectives A-Z. Available from: http://www.healthypeople.gov/2020/topicsobjectives2020/objectiveslist.aspx?topicid=23. Accessed February 23, 2017.

5. Laugesen MJ, Mistry R, Carameli KA, Ribisl KM, Needleman J, Bastani R. Early policy responses to the human papillomavirus vaccine in the United States, 2006-2010. J Adolesc Health. 2014;55(5):659-664.

6. National Conference of State Legislatures. HPV vaccine: state legislation and statutes; 2017. Available from: http://www.ncsl.org/research/health/ hpv-vaccine-state-legislation-and-statutes.aspx. Accessed February 21, 2016.
Risk Management and Healthcare Policy

\section{Publish your work in this journal}

Risk Management and Healthcare Policy is an international, peer-reviewed, open access journal focusing on all aspects of public health, policy, and preventative measures to promote good health and improve morbidity and mortality in the population. The journal welcomes submitted papers covering original research, basic science, clinical and epidemiological

\section{Dovepress}

studies, reviews and evaluations, guidelines, expert opinion and commentary, case reports and extended reports. The manuscript management system is completely online and includes a very quick and fair peerreview system, which is all easy to use. Visit http://www.dovepress.com/ testimonials.php to read real quotes from published authors. 